\title{
NATIONAL STORIES AND NARRATIVE VOICE IN THE FICTION OF JOSHUA FERRIS
}

\author{
Ruth Maxey, University of Nottingham
}

\section{Introduction: Nation and Narration}

In his critically acclaimed, bestselling début novel, Then We Came to the End (2007), Joshua Ferris chooses a very particular voice to narrate his story of a pre-9/11

Chicago advertising agency, a voice much commented upon by reviewers: the firstperson plural. This technique is overtly highlighted when the collective narrator remarks that as successful copywriters,

we could demonstrate for our fellow Americans their anxieties, desires, insufficiencies, and frustrations - and how to assuage them all. We informed you in six seconds that you needed something you didn't know you lacked ...What, then, were we to make of an empty sketch pad or blank computer screen? ...What were we but sheep like them? We were them. We were all we - whereas for so long we had believed ourselves to be just a little bit above the others (Then We Came to the End 234-235).

Despite the writerly assurance of such a passage - which is as much about 'our fellow Americans', figured as 'you' and 'them', as it is about 'we' the employees - Ferris has admitted that it took him around six years to write Then We Came to the End because he 'couldn't figure out the first person plural' (quoted in Higginbotham). Yet Ferris seems to relish the challenge of what Jeffrey Eugenides has termed 'impossible voices' (quoted in Foer) because he returns to a shifting and at times unusual narrator in his second novel, The Unnamed (2010). Here he ranges from a conventional, free indirect, third-person singular voice to 'you' and 'I', 'they' and 'we'. And in his most recent novel, To Rise Again at a Decent Hour (2014), which begins with the 'I' narrator common to much modern fiction in English, a different, anonymous, firstperson singular voice quickly emerges: that of the man impersonating and stalking the 
protagonist, Paul. This results in the illusion of a split self as 'Paul' (later revealed to be Grant Arthur) speaks to the real Paul and vice versa.

Ferris has claimed that 'I don't set out to experiment' (cited in Davidson), yet he has also remarked that 'I hope to take all the approaches that are available to a writer ...[and] never feel repetitive' (quoted in Paskin). To that end, he has deployed unusual forms of narrative voice in each of his three novels to date. In using such formal techniques, he poses wider philosophical questions, with the 'we' narrator of Then We Came to the End, for example, serving an abstract discursive purpose as much as a literary one: a fresh narrative voice deployed to reflect both a particular American environment and the dawn of a new century. Indeed, in every novel, to a greater or lesser degree, Ferris links narrative experimentation to the national zeitgeist, and he does so to sometimes risk-taking and unsettling effect. His fiction invariably engages with the idea of America and in his national narratives, Ferris sets out to interpret the United States in new ways. In this respect, he can be connected to older US writers such as Toni Morrison and Philip Roth who employ narrative pronouns both formally and in a thematic sense to examine the nation in novels which include Morrison's The Bluest Eye (1970) and Roth's The Human Stain (2000). In similar fashion, Ferris regards 'I', 'you', 'we' and 'they' as integral to exploring and interpreting America and to exposing the unstable nature of reality.

Narrative voice, personal pronouns and the state of the nation are thus closely connected in Ferris's work and it is this relationship that I will analyse here. At the same time, I will ask whether - following the bold and sustained experimentation of Ferris's collective narrator in Then We Came to the End - he has become more conservative in narrative terms in his subsequent fiction. If so, why might this be? And how has this ostensible shift impacted upon his thematic material? Has such 
material conversely come to be more ambitious and interrogative of the contemporary United States as Ferris's employment of narrative voice has become less daring? In seeking to answer such questions, I will investigate a writer whose work has received much popular attention, but little academic interest to date, ${ }^{1}$ and I will therefore address that scholarly neglect. Commentators have said little about the formal experimentation in Ferris's later novels ${ }^{2}$ and, although he has published 12 short stories since 1999, such material remains critically ignored. I will make reference to that short fiction and to his second and third novels throughout this essay but I will focus primarily on Then We Came to the End because, within Ferris's $2 u v r e$, it is the text where narrative innovation is most clearly related to the idea of America.

\section{Connecting narrative voice with America in Then We Came to the End}

Wyatt Mason has argued, in relation to Then We Came to the End, that 'one strains to find ten examples' of what he terms 'an orphaned narrative mode' and that reviewers' 'suggestions that this "first-person collective" narration was any more "technically challenging" than, say, "third-person omniscient" or "unreliable first person" were wrongheaded' (Mason 69). I would contend, by contrast, that the collective narrator is a technically demanding form. It can be especially difficult for a writer to sustain a novel told in the first-person plural because of the greater imaginative and psychological limits this imposes. It can even become creatively impossible to sustain a 'we' voice throughout an entire narrative, especially a lengthy one. Arguably, this is because such a narrator renders the task of achieving a strict mimesis of reality so much more difficult (Richardson 42, 58). The first-person plural voice is often essentially unknowable - with its inherent ambiguity as both inclusive and exclusive of the reader - and this may explain why it still remains relatively 
unusual in American letters. Yet this 'narrative mode' has a family history in American literature going back to such 19th-century predecessors as Nathaniel Hawthorne (Marcus 4-5); and within the 20th century, well-known practitioners include William Faulkner, Donald Barthelme, Susan Sontag and Eugenides. Since 9/11, moreover, a host of US 'we' narratives has appeared by writers ranging from Kate Walbert to Julie Otsuka, perhaps as a means of offering an alternative American 'we' to the post-9/11 model of patriotism presented by the Bush administration and its attendant pressure upon national subjects to belong and conform.

In Then We Came to the End, the collective narrator reflects a particular community but - unlike the small-town 'we' of such short stories as Faulkner's "A Rose for Emily" (1930) and Steven Millhauser's “The Knife Thrower" (1998) or novels including Eugenides' The Virgin Suicides (1993) and Walbert's Our Kind (2004) - this is a professionalised 'we': the voice of the workplace. Ferris's firstpersonal plural voice therefore anticipates the laboratory team of Seth Fried's later short story, "Loeka Discovered" (2008). But unlike the enclosed, rarefied, research environment of Fried's fictional lab, where the team's endeavours might be linked to an academic 'we' (Hyland 200-201, 208-210), Ferris employs his collective narrator to represent US corporate life and what it means to belong to an explicitly capitalist venture. The novel's first-person plural voice is arguably the perfect vehicle to investigate ideas of corporate belonging, office life as familial substitute, and American consumerism. After all, advertising seeks to capture the public mood and make collective pronouncements. And whereas Fried's researchers in "Loeka Discovered" must surrender their individuality to the greater good of scientific knowledge, the activities of Ferris's copywriters are less high-minded. At the same time, the novel's collective stance ensures a timeless, universal quality in common 
with other recent US 'we' narratives and transcends the particular details of Chicago adland in the late 1990s to derive a broader allegorical meaning from this world.

Then We Came to the End exposes as a pretence the official language of togetherness and certainty in corporate America because, as the reader learns early in the novel, staff may be laid off at any moment. In narrative terms, a sense of security is undermined because the reader never really knows who is speaking. The novel's destabilised, floating narrative voice indicates a superficially uniform and inclusive, but actually highly unsettling and excluding, corporate culture. Through the dynamics of 'us' versus 'them', 'they' - the senior management and real decision-makers, especially the mysterious figure of Lynn Mason, a partner in the firm - are left even more vague than Ferris's shifting 'we'. This lack of knowledge about the higher echelons of the firm reflects the vulnerability of junior staff facing a perilous future, a workforce which - like Walbert's group of elderly, affluent WASP women in Our Kind - draws on a collective voice to generate a largely futile bravado: "we knew everything, we had terrible powers, we would never die' (Then We Came to the End 92). But these are relatively powerless employees. When Joe Pope comments that Lynn and he are 'not talking personal matters ...We're talking about ways to keep this place from going under' (251), Joe's 'we' is distinguished from that of the petty, tale-telling faction represented by the junior staff: that is, the small team of copywriters, not laid off immediately, who comprise the heart of the collective narrator.

This first-person plural narrator is, like earlier examples of that voice in American literature, open to multiple interpretations. It could signify everything from the world of work to debates around individual and national belonging. 'We' is arguably all of these things. Since it is inclusive - with several reviewers regarding 
the reader as addressee (O'Grady, Upshaw) - but also excluding and opaque, Ferris's collective voice creates suspense right from the title of the novel, adapted from the opening sentence of Don DeLillo's first novel, Americana (1971; see Cosper), until its conclusion. The connection between the novel's narrator and US identity is invoked specifically when the text considers the place of advertising as a voice of America. Yet when Ferris writes of the US public, 'what were we but sheep like them? We were them. We were all we' (235), the collective pronoun of national belonging is defamiliarised, broken down and hollowed out: semantically, socially and existentially.

This connects to the precarious balance between group belonging and an inner sense of self (compare Bland), an issue highlighted pronominally when the threat of redundancy looms large:

words and meaning were almost always at odds with us. We knew it, you knew it, they knew it. The only words that ever meant a goddamn were, 'We're really very sorry about this, but we're going to have to let you go' (Then We Came to the End 329).

The 'we' narrator's self-reflexivity draws upon a peculiarly American tension between the need for unity and conformity and the drive for individualism and diversity, embodied in the phrase e pluribus unum or 'out of the many, one'. Genevieve Latko-Devine evokes this quintessentially American motto when she defends individual rank-and-file colleagues to Joe as 'one of many' (252). Perhaps Ferris is thinking back to the historical relevance of this phrase in the US national context (compare Gerstle 524-558), and its renewed media significance through the Ad Council's 'I am an American' advertising campaign after the events of September 11th, 2001 (see Weber). After all, although the novel is set in a pre-9/11 America, its writing and publication took place in the years that followed this national tragedy. 
Beyond the utopian promise of e pluribus unum, the core 'we' of the novel is nevertheless quite specifically racialised and gendered, thus recalling the black American 'we' rejected by Coleman Silk in Roth's The Human Stain: a direct influence upon Ferris (quoted in Fassler). In Then We Came to the End, the issue of identity politics is foregrounded in Chapter 1 of Book 1: 'layoffs were upon us ...If you were lucky, you could sue. If you were black, aged, female, Catholic, Jewish, gay, obese, or physically handicapped, you had grounds' (15). Ferris is careful to outline social pluralism here, strategically replacing 'we' with 'you', in a novel whose individual characters can indeed be defined in one or more of the ways listed. Yet he also implies a particular norm. That norm is unracialised and ungendered, secularised and sexually specific. It is the physically fit, young to middle aged, heterosexual white man who practises no particular religion. Such men, who bear some resemblance to Ferris himself, make up the bulk of the collective narrator: Tom Mota, Jim Jackers, Larry Novotny, Dan Wisdom, Carl Garbedian, Don Blattner, Chris Yop and - colleagues' prurience about his sexual orientation aside - Joe Pope.

This presumption of straight white masculinity is a key feature of the worldview within Ferris's other novels, too. Their protagonists - Tim Farnsworth in The Unnamed and Paul O'Rourke in To Rise Again at a Decent Hour - both fit this model. At the same time, the traditional social and/or economic dominance of such American men is also interrogated within each novel. In Then We Came to the End, the position of such white men may be socially significant, but it is also legally precarious, since their normative, majority status makes them less able to seek redress in the face of redundancy. In The Unnamed, Tim's white 'master of the universe' standing as a highly successful New York attorney is brutally stripped away by his debilitating and mysterious condition, while Paul's emotional and spiritual emptiness 
in To Rise Again at a Decent Hour render him a much more vulnerable figure than the wealthy, professionally established and outwardly arrogant Manhattan dentist he first appears to be.

Despite Ferris's longstanding personal awareness of being 'a white man in a white man's world' (quoted in Fassler) along with the concomitant political advantages and creative disadvantages of this position, there remains an uncomfortable relationship with racial difference and racialised language across his fiction, including some of his short stories, such as "The Valetudinarian" (2009), where the third-person narrator refers to a character as 'Oriental' ("Valetudinarian" 61), and "The Fragments" (2013) where the 'Jamaican' and 'Asian' status of two New York women must, it appears, be pointed out ("Fragments" 65). In Then We Came to the End, such ethno-racial tensions are highlighted by the creative team's attitude towards Karen Woo, a Korean American co-worker:

we hated hating Karen Woo because we feared we might be racists. The white guys especially. But it wasn't just the white guys. Benny [Shassburger], who was Jewish, and Hank, who was black, hated Karen too. Maybe we hated Karen not because she was Korean but because she was a woman with strong opinions in a male-dominated world (111).

Despite its hedges, the 'we' which rejects Karen is, broadly speaking, the white American man whose power has become threatened. ${ }^{3}$ And the type of 'white guys' present in Then We Came to the End 'place responsibility for a broad series of shifts in labour opportunity at the feet of the women and people of colour who have displaced them' (Carroll 3). It is 'the white guys', then - and Larry and Joe specifically - who react to Karen's ideas, respectively belittling and praising them. And reflective of this masculine fear of women 'with strong opinions in a maledominated world', the misogynistic Tom harangues Carl's white wife, Marilyn, a 
successful oncologist, thus demonstrating a male rage against perceived emasculation which goes beyond racial difference.

While embodying and exploring the dynamics of self-preservation, the firstperson plural narrator of Then We Came to the End implies that much of the freedom to be truly individual has disappeared, ground out of its characters by years of having to answer to a wider social system: whether that is the group dynamics of high school or the demands and routines of working life in America. It is revealing that characters are generally spoken for, their direct speech often remembered and recorded by others, with the result that the reader gains only limited access to their inner thoughts. This supposedly collective voice exposes the public, yet anonymous, face of US office life since, despite a lack of privacy, colleagues can never entirely know one another and, to perhaps a greater extent than other examples of the form in American fiction, it is impossible to pin down the identity of 'we' or 'us' in this novel. After all, Ferris's 'we' constantly branches off into stories of individual characters, narrated in the third-person singular. This also relates to the distinction made by Janet Burroway and Elizabeth Stuckey-French between the 'central' and 'peripheral' first-person singular narrator, whereby the latter is 'in virtually any position that is not the centre' (Burroway and Stuckey-French 301). Ferris's unidentifiable, 'peripheral' collective narrator reflects colleagues' surface-level relationships which result precisely from their close proximity to each other.

In this world of collective pronouncements, both internal and external - and a chain of command hidden by the faux togetherness of a 'we' rhetoric - the expression of individual opinion is reduced and the first-person plural pronoun thus implies a kind of US corporate censorship, too. This could explain why those employees who do speak or act out do so dramatically in startling setpieces: for instance, when Tom 
speaks in the first-person singular in increasingly eccentric and rambling emails (an idea extended by Ferris in the email sections of To Rise Again at a Decent Hour) and after being laid off, returns to the office to stage a hoax shooting; or when Carl makes himself seriously ill by stealing and consuming another colleague's medication.

Ferris's 'we' also has moral implications. It may suggest the pomposity and impersonality of nosism or the royal 'we', which Ferris believes has been replaced with 'a corporate "we"' in America' (quoted in Higginbotham). This voice can lend itself to deception, whether by claiming praise for work done by somebody else or through the workplace reality of deflecting responsibility: the buck-passing and sheer sense of safety in numbers ensured by the erasure of a directly individual personal pronoun (compare Drury 11; Marcus 3). As Tim Adams argues of Ferris's collective narrator, 'all individual "I"s [are]...subsumed into an inescapable, suffocating and often hilariously cowardly "we": the novel as internal memo' (Adams). This point can also be linked to Millhauser's notion that 'the moral wavering of ..."we" ...is more disturbing than the moral wavering of an 'I' would have been' (cited in Chénetier). In Ferris's novel, 'we' behave in a herd-like fashion, eavesdropping and spying on others at the same time as, ironically, fearing surveillance by the powers that be. This link between spying and a collective voice recalls both "A Rose for Emily" and The Virgin Suicides. In Then We Came to the End, it occurs when staff secretly watch their colleague, Janine Gorjanc, a bereaved mother, in the play area of a local McDonalds. Here a shifting narrative voice signals the questionable morality of these activities:

Over the course of the next few weeks, practically everyone made it over to the McDonalds. If Karen couldn't go, they went without her. That is to say, we went without her ... It wasn't something you could afford to miss. You had to go... (131; emphasis in original). 
'They' to 'we' implies an admission of guilt, while 'you' apportions blame even more widely for this unsavoury behaviour while seeking to justify it, with 'you', but not 'I', experiencing a compulsion to participate.

This conduct is in some way removed from the full-blown community bullying and scapegoating Morrison suggests in her switch to a collective voice at the end of The Bluest Eye, where, as some critics have argued, the reader is made complicit in humanity's failure to protect the vulnerable (McKenzie 223). Yet readers of Then We Came to the End - a much gentler text than Morrison's still shocking protest novel - may feel a stab of recognition as they are forced, in their position as implied addressee ('we'/'you'), to examine their own participation in the worst aspects of social and/or corporate behaviour and their own weakness in the face of peer pressure and a mob mentality. Swept along by the collective power and momentum of Ferris's novel, readers are thus subsumed within this narrative voice, especially in the novel's final sentences where, recalling its title, 'we' have come to the 'end': 'we were the only two left. Just the two of us, you and me' (Then We Came to the End 385). 'We' the reading audience have shared in the spying and speculation, suspense and human interest; and in its dual narratee/addressee function, the closing sentence makes us feel our involvement. This has intriguing implications for Ferris's novel as national narrative, since non-Americans as much as US readers may experience the sense of being addressed: the polysemic nature of 'you' in English, simultaneously singular and plural, formal and informal, can be extended to a more universal utterance. The 'end' is historical, too, and can be read as the destruction and loss of certainty wrought by the terrorist attacks of $9 / 11$. The novel's fictionalised run-up to these events is depicted as prelapsarian - 'that more innocent time' (357) with $9 / 11$ rendered allusively as 'the end of another bright and tranquil summer' 
(357). This circumlocution, suggesting that which cannot be spoken, is arguably more powerful than a direct discussion of the traumatic impact of $9 / 11$, which lies outside the purview of the particular national story Ferris wishes to tell.

When Ferris's 'we' fades into the background, other stories can be told, stories which cannot be narrated in a collective voice because the group is not present: 'we' cannot know everything. In a narrative structure which is recursive and non-linear, such episodes can be virtuosic, particularly Lynn's long night of the soul, “The Thing to Do and the Place to Be", a storytelling tour de force of 34 pages which appears just over half-way through the novel and is told in a free indirect, third-person singular voice. This represents a break from 'we', the office and the memo-style, executive summary, storyboarding prologue to each chapter.

It emerges at the end of the novel that "The Thing to Do" is actually Hank Neary's re-imagined version of events: another form of speculation. Despite his multiple minority status as black, gay, and learned within an office community underpinned by presumptions of white male heteronormativity and with no particular regard for erudition, this aspiring novelist ultimately takes centre stage as the driving force behind the main narrative. This twist feels like something of an afterthought in relation to the identity politics of the novel as a whole. That is, when Ferris attempts to move away from the 'we' of straight white masculinity, it is with mixed and less than convincing results. Whatever the parallels between Ferris and Hank - namely, their status as highly literate men and would-be writers employed by Chicago advertising agencies (the author's lived experience that inspired this novel) - I disagree once again with Mason, who claims that 'there can be little doubt that Hank Neary's views are Ferris's own' and that he is 'Ferris's mouthpiece' (Mason 70). It seems crudely reductive to read Hank simply as a stand-in for Ferris, a move Mason 
even acknowledges as 'typically unwise' (Mason 70). Hank is, of course, a fictional creation and an outsider to the imagined, homodiegetic reality of Then We Came to the End in ways that in the real-life world of his own work environment, Ferris was arguably not. And this is surely deliberate, since Hank's vantage point as multiply Other within the novel's advertising agency is in some ways the ideal one for Burroway and Stuckey-French's 'peripheral' narration. This is because the novel concludes with him as 'me' against a subversively deployed 'we' of tentative and temporary workplace alliances which have broken down altogether. When 'we' come to the 'end', Hank is the 'one' out of the 'many' in this national narrative, where Ferris injects the collective narrator of contemporary American fiction with his own brand of comedy, pathos and seriousness.

\section{Narrative pronouns and the state of the nation in Ferris's more recent fiction}

In conclusion, I have sought to show the risk-taking connection between narrative voice and contemporary American stories in Then We Came to the End. Following this use of a flamboyantly unusual narrator, it is tempting to argue that Ferris's subsequent writing has become formally more conservative and that narrative voice is less closely linked to state-of-the-nation concerns. Yet this is not necessarily so. The Unnamed and To Rise Again at a Decent Hour may begin with more conventional narrators than Ferris's début novel, but they remain technically experimental. They are also intellectually ambitious and openly critical of American life.

Thus, The Unnamed is powered by its protean narrative voice and by the social and ethical questions about 21st-century America posed through the figure of its isolated protagonist and through the novel's use of linguistic defamiliarisation and 
textual lacunae. And in To Rise Again at a Decent Hour, Ferris thematises and interrogates pronouns in his examination of contemporary US society. As with Then We Came to the End, he unpacks 'we' in particular, but this time in order to investigate the psychology of the American sports fan and of 'the mutt-y white guys' (quoted in Lee) who apparently lack a proper ethnic and religious identity and envy the ethno-religious certainties they perceive in others. In this exploration of modern white American masculinity, the collective pronoun is again deconstructed, opened up to new meanings, and treated as an inherently unstable and contradictory phenomenon. Despite continuing echoes of Roth's The Human Stain where Coleman resists 'the tyranny of the ...coercive, inclusive, historical, inescapable moral we with its insidious E pluribus unum' (Roth 108), Ferris nevertheless reclaims the pronoun and makes it fresh. Indeed, the reader is once more forced to re-examine an overly familiar unit of everyday language and question its emotional, linguistic and historical power in a current American context.

Meanwhile, a short story such as "The Fragments" employs the polyphony of half-heard urban conversations, thus recalling Tim's eavesdropping on his fellow New Yorkers in The Unnamed and the multiple first-person narrators of an earlier short story, "Ghost Town Choir" (2006). And such other stories as "The Valetudinarian", "The Pilot" (2010) and "The Breeze" (2013) are ambiguous, concept-driven, thematically daring stories which employ open endings and sometimes embed alternative dramatic possibilities within the text itself. Narrative voice is changeable even in the most traditional of Ferris's short stories: for instance, "More Abandon" (2005), which begins with 'they', switches to 'he' and then briefly shifts back to 'they' for dramatic effect; and "More Afraid of You" (2008), where the passage of years at the end of the story is signalled by a sudden change in narrator 
from different third-person singular perspectives to a quasi-autobiographical, Rothian 'I' voice, who reveals himself as 'Josh' by identifying that this is also the name of his 'cousin's fiancé' (234). And the apparently conventional narrative 'he' of "The Dinner Party" (2008) is never named.

Without being overtly metafictional, Ferris implies that there is no such thing as a stable narrative voice and captures competing American realities in a rapidly changing society through shifting narrators within his short and longer fiction. In Then We Came to the End, that national reality is advertising; in The Unnamed, another state-of-the-nation narrative, it is the American Dream turned nihilist American odyssey, as one individual walks across the country, witnessing the effects of climate change and the limits of healthcare; and in To Rise Again at a Decent Hour, it is baseball, a countrywide obsession with good teeth, and an all-American quest for religious belonging which cuts across ethnic and social differences. Ferris shifts from an obviously collective America in his first novel to investigations of contemporary US individualism through urban men: 'he'/Tim Farnsworth, forced to endure a rugged, classically American existence of wilderness survival and western movement, in The Unnamed; and 'I'/Paul O'Rourke as metropolitan, cyber-age individual in peril in To Rise Again at a Decent Hour.

For Ferris, narrative and thematic experimentation is crucial in telling new American stories or older national stories in new ways. Yet critics have generally overlooked this fundamental relationship in his writing, at least as it has continued beyond the eye-catching first-person plural narrator of Then We Came to the End. ${ }^{4}$ Alternately intrigued and frustrated by his longer fiction as novels of ideas, many reviewers have produced synoptic, tendentious or overly opinionated responses, failing to consider the ways in which Ferris seeks to fulfil his self-confessed ambition 
'to take all the approaches that are available to a writer ... [and] never feel repetitive' (quoted in Paskin). There may be some truth in the idea, suggested in the introduction to this essay, that Ferris's material has become more dynamic thematically in his second and third novels - To Rise Again at a Decent Hour ranges particularly widely in discursive terms - but he has in fact always maintained a daringly contemporary focus. And it would appear that like other Anglophone/American writers - Mohsin Hamid, Millhauser and Morrison, for instance - he continues to be drawn to narrative voices which challenge and even implicate the reader. They are not simply a feature of his early work, confined to an isolated novel or short story. Rather than being merely a gimmick, such changing narrators - which reveal complex processes of identification and detachment, empathy and disdain, belonging and alienation - form an uncompromising bid to chart life and death in 21 st-century America.

\footnotetext{
Notes

${ }^{1}$ For a rare exception, see Ferry.

${ }^{2}$ The Unnamed initially seems to be written in a more conventional vein than Then We Came to the End, yet in terms of narrative voice, it is actually a much more experimental novel than it first appears. Goldberg makes a brief reference to Tim's unreliable point-of-view, but most critics have failed to spot its technical and narrative ambition, focusing instead on its thematic experimentation, unremitting bleakness and the clear break in tone it offers from the humour and levity of Ferris's début novel. ${ }^{3}$ Within this rather old-fashioned ethno-racial model, Benny's Jewishness seems to place him outside the novel's implied norm; compare Brodkin and Gerstle 555-556.

${ }^{4}$ Gerrard is thus unusual in recognising the shift in narrative voice in To Rise Again at a Decent Hour from Ferris's first two novels.
} 


\section{Works Cited}

Adams, Tim. "The Unnamed by Joshua Ferris.” The Observer. 21 Feb. 2010. 20

Aug. 2014. <http://www.theguardian.com/books/2010/feb/21/the-unnamedjoshua-ferris $>$.

Bland, Archie. "The Unnamed, By Joshua Ferris.” The Independent. 26 Feb. 2010. 20 Aug. 2014. <http://www.independent.co.uk/artsentertainment/books/reviews/the-unnamed-by-joshua-ferris-1910815.html> .

Brodkin, Karen. How Jews Became White Folks And What That Says About Race In America. New Brunswick, NJ: Rutgers UP, 1998.

Burroway, Janet, and Elizabeth Stuckey-French. Writing Fiction: A Guide to Narrative Craft. New York: Pearson Longman, 2007.

Carroll, Hamilton. Affirmative Reaction: New Formations of White Masculinity. Durham, NC: Duke UP, 2011.

Chénetier, Marc. “An Interview with Steven Millhauser.” Transatlantica 1 (2003). 20 Aug. 2014. <http://transatlantica.revues.org/562>.

Cosper, Darcy. “Office politics, cubed.” Los Angeles Times. 11 March 2007. 20 Aug. 2014. <http://articles.latimes.come/2007/mar/11/books/bk-cosper11>.

Drury, Donald. “The Lofty and/or Assumptive We." Verbatim 12.3 (1986): 11-13.

Fassler, Joe. "Taking Sides in the Great Literary Divide Between Nabokov and Roth." The Atlantic. 1 July 2014. 20 Aug. 2014.

$<$ http://www.theatlantic.com/entertainment/archive/2014/07/confronting-privilegein-philip-roths-identity-tales/373782/>.

Ferris, Joshua. “More Abandon.” Best New American Voices 2005. Ed. Francine Prose. Orlando: Harcourt, 2004. 134-154. 
-----. “More Afraid of You.” Granta 101 (2008): 217-235.

-----. Then We Came to the End. London: Penguin, 2008.

-----. "The Valetudinarian.” The New Yorker 3 Aug. 2009: 58-66.

-----. The Unnamed. London: Viking, 2010.

-----. “The Fragments.” The New Yorker 29 April 2013: 64-69.

-----. To Rise Again at a Decent Hour. London: Viking, 2014.

Ferry, Peter. "Reading Manhattan, Reading American Masculinity: Reintroducing the Flâneur with E.B. White's Here Is New York and Joshua Ferris' The Unnamed." Culture, Society and Masculinities 3.1 (2011): 49-61.

Foer, Jonathan Safran. “Jeffrey Eugenides by Jonathan Safran Foer.” Bomb (2002). 20

Aug. 2014. <http://bombmagazine.org/article/2519/jeffrey-eugenides>.

Gerrard, David Burr. "Compulsive Individuality." Rev. of To Rise Again at a Decent Hour. Los Angeles Review of Books. 2 June 2014. 20 Aug. 2014.

$<$ https://lareviewofbooks.org/review/compulsive-individuality $>$.

Gerstle, Gary. "Liberty, Coercion, and the Making of Americans." Journal of American History 84.2 (1997): 524-558.

Goldberg, Tod. “"The Unnamed' by Joshua Ferris.” Los Angeles Times. 17 Jan. 2010. 20 Aug. 2014. <http://articles.latimes.com/2010/jan/17/entertainment/laca-joshua-ferris17-2010jan17>.

Higginbotham, Adam. “Workers’ playtime.” Daily Telegraph. 31 March 2007. 20 Aug. 2014. <www.telegraph.co.uk/culture/3664145/Workers-playtime.html>. Hyland, Ken. "Disciplines and Discourses: Social Interactions in the Construction of Knowledge." Writing in Knowledge Societies: Perspectives on Writing. Ed. Doreen 
Starke-Meyerring, Anthony Paré, Natasha Artemeva, Miriam Horne and Larissa

Yousoubova. Fort Collins, Colorado: The WAC Clearinghouse and Parlour Press, 2011. 193-214.

Lee, Jonathan. “Always on Display: An Interview with Joshua Ferris.” The Paris Review. 19 May 2014. 20 Aug. 2014.

$<$ http://www.theparisreview.org/blog/2014/05/19/an-interview-with-joshuaferris/>.

Marcus, Amit. "We are you: The plural and dual in 'we' fictional narratives." Journal of Literary Semantics 37 (2008): 1-21.

Mason, Wyatt. “The Untamed: Joshua Ferris's restless-novel syndrome.” Harper's Magazine (Feb. 2010): 69-73.

McKenzie, Marilyn Mobley. "Spaces for readers: the novels of Toni Morrison." The Cambridge Companion to the African American Novel. Ed. Maryemma Graham. Cambridge: Cambridge University Press, 2004. 221-232.

O’Grady, Carrie. “Office hours.” The Guardian. 5 May 2007. 20 Aug. 2014. $<$ http://www.theguardian.com/books/2007/may/05/ featuresreviews.guardianreview18>.

Paskin, Willa. “Joshua Ferris Discusses His New Novel, 'The Unnamed'.” Black Book. 6 Jan. 2010. 20 Aug. 2014. <http://www.bbook.com/joshua-ferrisdiscusses-his-new-novel-the-unnamed/>.

Richardson, Brian. Unnatural Voices: Extreme Narration in Modern and Contemporary Fiction. Columbus: Ohio State UP, 2006.

Roth, Philip. The Human Stain. London: Vintage, 2005.

Upshaw, Reagan. "Tender view of life among the cubicles.” San Francisco Chronicle. 4 March 2007. 20 Aug. 2014. 
$<$ http://www/sfgate.com/books/article/Tender-view-of-life-among-the-cubicles2644375.php>.

Weber, Cynthia. "II Am an American': portraits of post-9/11 US citizens.” Open

Democracy. 11 Sept. 2007. 20 Aug. 2014. <www.opendemocracy.net/

article/i_am_an_american_portraits_of_post_9_11_us_citizens $>$. 